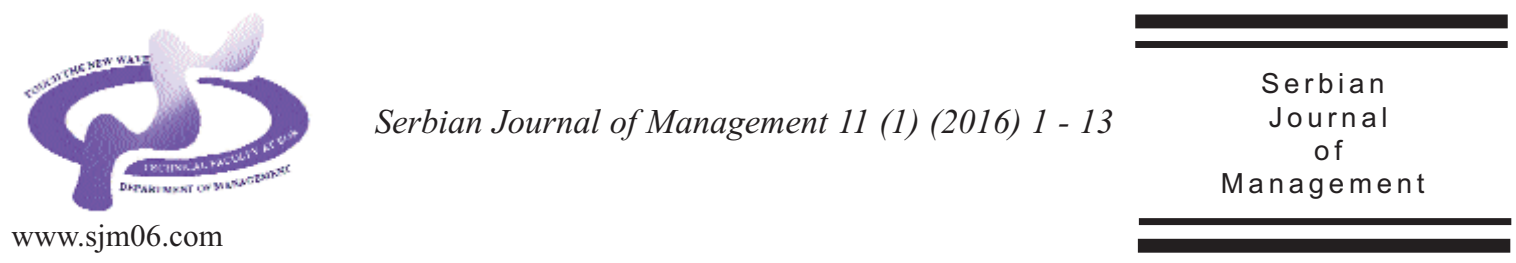

\title{
INCORPORATING MCDS AND VOTING INTO SWOT - BASIC IDEA AND EXPERIENCES
}

\author{
Jyrki Kangas ${ }^{a *}$, Miika Kajanus ${ }^{b}$, Pekka Leskinenc and Mikko Kurttilad \\ $a_{\text {University of Eastern Finland, Department of Forest Sciences }}$ \\ P.O. Box 111,80101 Joensuu, Finland

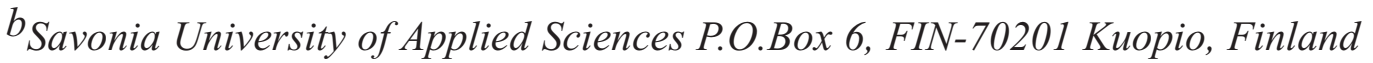 \\ ${ }^{c}$ Finnish Environment Institute, Centre for Sustainable Consumption and Production \\ P.O. Box 111, 80101 Joensuu, Finland \\ $d_{\text {Natural Resources Institute Finland P.O. Box 68, } 80101 \text { Joensuu, Finland }}$
}

(Received 4 December 2015; accepted 7 January 2016)

\begin{abstract}
The idea in using Multiple Criteria Decision Support (MCDS) and voting methods within a SWOT framework is to evaluate systematically the SWOT factors, and to assess them with respect to their priorities. The MCDS method applied initially, and most often, with SWOT has been the Analytic Hierarchy Process (AHP), and the hybrid AHP-SWOT approach has been called the A'WOT. Any MCDS method can, however, be applied; the choice of the method depending on the strategy process in question. In this article, experiences of using the A'WOT method with AHP, SMART and SMAA-O techniques is summarized. In addition, an illustrative example of making use of social choice theory within SWOT framework is presented. The hybrid MCDS-SWOT approach has gained growing popularity, and it has been applied in different fields world-widely. It may provide not only a solid decision support but also an effective framework for learning in strategic decision support, as well as for communication in strategy processes with multiple stakeholders. The Voting-SWOT approach (VotSWOT) fits especially well with participatory strategy processes, as it reflects decision makers' and stakeholders' natural ways of communication.
\end{abstract}

Keywords: A'WOT, multiple criteria decision support, natural resources management, strategic management, voting methods

\section{INTRODUCTION}

SWOT analysis is a commonly-used tool for analysing operational environments in order to attain both a systematic approach and support for strategic decision making. In a SWOT analysis, the internal and external factors most important for the future success

\footnotetext{
* Corresponding author: jyrki.kangas@uef.fi

DOI:10.5937/sjm11-9661
} 
of a company (or any decision maker) are grouped into four categories: strengths, weaknesses, opportunities and threats. The purpose of applying SWOT is usually to develop and adopt a strategy resulting in a good fit between the internal and external operational environments as well as with the objectives of the decision maker.

SWOT could, however, be used more efficiently and in a more versatile manner than has normally been the case when applying it. Too often, it has remained at the level of just pinpointing the factors. Furthermore, SWOT itself includes no means for analysing the importance of the factors or for evaluating the decision alternatives with respect to the factors. Thus, the further utilization of SWOT alone is mainly based on qualitative analyses made in the decision-making process, and on the capabilities and expertise of the persons participating. It is not a surprise, that research has aimed at enhancing the use of SWOT as a practical planning tool in many ways, e.g., by connecting other strategic planning tools to it (Helms \& Nixon 2010).

The idea in using Multiple Criteria Decision Support (MCDS) methods within a SWOT framework is to assess systematically the SWOT factors and to make them commensurable (Kurttila et al., 2000). This enables more analytical SWOT procedures. The hybrid method A'WOT makes combined use of the Analytic Hierarchy Process (AHP) (Saaty, 1980) and SWOT. It was first presented by Kurttila et al. (Kurttila et al., 2000), who applied it to natural resources management.

After carrying out the assessments required by the AHP, quantitative information that is useful in the strategy process can be obtained about the decision problem. On the basis of comparisons of the
SWOT factors and groups one can analyse, for example, whether there is a specific strength or weakness requiring most of the attention, or if the organisation is expected to be faced with future threats exceeding its combined opportunities. In addition, use of A'WOT enables choice alternatives to be prioritized with respect to each SWOT factor and to each SWOT group. When the importance of different SWOT groups have also been determined, it is possible to evaluate decision alternatives with respect to the strategic choice situation as a whole.

The objective of this paper is to summarize experiences on the use of MCDS techniques together with SWOT in strategic management. The MCDS methods reviewed more closely are AHP (Saaty, 1980), SMART (Edwards \& Barron, 1994) and SMAA-O (Miettinen et al., 1999; Lahdelma et al., 1998). Furthermore, possibilities to apply voting methods instead of MCDS with SWOT is examined.

\section{MCDS METHODS IN THE SWOT FRAMEWORK}

In general, the hybrid methods that combine SWOT and MCDS proceed as follows:

(i) The SWOT analysis is carried out. The relevant factors of the external and internal environments are identified and included in SWOT analysis.

(ii) The relative importance of the SWOT factors are determined separately within each SWOT group. Any Multiple Criteria Decision Support (MCDS) method, and its comparison principles, can be applied.

(iii) The relative importance of the SWOT groups are determined. There are several principles of doing this and also here any 
MCDS method can be applied.

(iv) The decision alternatives are evaluated with respect to each SWOT factor according to the comparison rules of the applied MCDS method.

(v) Global priorities may now be calculated for the decision alternatives in accordance with the MCDS aggregation techniques.

The most often used MCDS method with SWOT, and the original one what comes to the A'WOT, is the AHP. The central characteristics of the AHP include pairwise comparisons of the elements of SWOT. In the original AHP, the ratio scale priorities describing the relative values of the SWOT factors, or the decision alternatives, are estimated by using the eigenvalue technique (Saaty, 1980). The ratio scale pairwise comparisons data can also be analysed through regression techniques (De Jong, 1984). In many cases, these two estimation methods give similar numerical results. Advantages of the regression approach include versatile possibilities to analyse the inherent uncertainties of the estimated priorities (Alho \& Kangas, 1997; Leskinen \& Kangas, 2005).

Also SMART method has been utilized together with SWOT (Kajanus, 2009; Kurttila et al., 2009). In the simple rating version of SMART, the importance of the SWOT factors can be defined as follows: one hundred points is given to the most important SWOT factor inside the examined SWOT group and the importance of other SWOT factors are numerically determined with respect to the most important factor. It is also possible to define the importance of the SWOT factors by allocating total of 100 points for SWOT factors according to their priority separately in each SWOT group. In addition to these fundamental versions, there is a collection of different SMART techniques and modifications, and one can recognise a whole methodological SMART family. Modifications include also two approximate methods called SMARTS and SMARTER (Edwards \& Barron, 1994). The original SMART makes use of an additive model, but non-additive versions have also been presented (Barzilai \& Lootsma, 1997). This is, in fact, possible also with AHP (Leskinen \& Kangas, 2005).

SMAA-O, in turn, belongs to the family of SMAA methods (Stochastic Multicriteria Acceptability Analysis), which have been developed for discrete multicriteria problems where criteria data are uncertain or inaccurate (Lahdelma et al., 1998; Kangas et al., 2003). In SMAA-O it is possible to analyse cardinal as well as ordinal information (Miettinen et al., 1999). Thus, it is possible just to rank the SWOT factors instead of giving them cardinal priority values. The ranking is transformed into cardinal information through simulation (however, based on strong assumptions concerning the preference structures). Using SMAA-O, in addition to analysing what the recommended action is under certain priorities, it is possible to analyse which kind of priorities would support each action. Statistical techniques can also be utilised in the context of ordinal multi-criteria preference information (Leskinen et al., 2004).

The advantage of the pairwise comparisons technique is that the decisionmaker needs to consider only one pair of the SWOT factors at a time instead of simultaneously assessing several factors. On the other hand, the total amount of pairwise comparisons increases rapidly with the increased number of factors, particularly if the SWOT lists are long. The developed 
statistical models enable the analysis of the data based on fewer comparisons. An additional advantage of the pairwise comparisons technique and the statistical approach is that the inconsistency of the pairwise comparisons can be used in describing the uncertainty of the preference information gathered. For example, probabilities for events such as 'SWOT factor A is more important than SWOT factor B' can be estimated. Holistic assessments, in turn, are less laborious than large sets of pairwise comparisons. The drawback is that sometimes decision-makers find it very difficult to evaluate multiple items simultaneously, especially when the number of items is large.

To summarize, cardinal (i.e. ratio or interval scale) preference information enables versatile and deep decision support compared with ordinal information, but it also requires that decision-makers should really understand the questions used and also that the context of the decision problem is appropriate for the cardinal assessments. Ordinal scales are easier to understand and apply than cardinal ones, but the natural drawback is that the analysis of the data and output of the analysis will then be simplified.

\section{APPLYING VOTING METHODS WITHIN SWOT}

A practical problem with many decision support methods is that performing the necessary inquiries may be difficult for many reasons. If the used method demands many complicated questions, it also typically demands a lot of time and guidance.

One possibility to alleviate the problems of too laborious preference inquiries for stakeholders is to apply the social choice theory (Kangas et al., 2003). Social choice problems are typically tackled by using different modes of voting. That is why social choice theory is often called voting theory. Throughout the history of democracy, voting has proved to be an efficient tool for making choices among decision alternatives, e.g., in different kind of elections. Voting theory can be seen as a credible alternative in group decision making and participatory strategy processes, as in developing voting methods special attention has been paid to systems that are difficult to manipulate (Nurmi, 1995).

In social choice, individual preferences are combined into a collective choice (Martin et al., 1996). The social choice situation can be described with four dimensions: (i) voters or players, (ii) choice alternatives, (iii) the information of voter's preferences over the alternatives, and (iv) an aggregation device. So, the approach greatly resembles MCDS. When individual utility functions are combined, the aggregation could be interpreted as a social welfare function (Martin et al., 1996).

Of voting approaches, the simplest mode is plurality voting. It considers the preference ordering of voters, but only with respect to the best candidate. Each voter has one vote, and she/he votes for just one candidate. The candidates (or decision alternatives) are ranked according to the sum of votes and the candidate/alternative with the plurality of votes wins. No majority of votes is required.

When applying the approval voting, each voter votes for as many candidates as she/he wishes (Kangas et al., 2006). So, voters vote for all candidates they "approve". Each candidate approved by a voter receives one vote. The candidate receiving the greatest number of votes is the winner. This method 
is harder to manipulate by voters than plurality voting, as it requires information about the distribution of approvals of the alternatives in order to be manipulated (Nurmi, 1995). However, it tends to promote moderate candidates.

The approval voting is argued to be the best voting system in cases where the real preferences of voters are dichotomous (Yilmaz, 1999). This might not be the case but occasionally. However, trichotomous or multichotomous preferences can also be applied. Yilmaz proposed a system where voters classify the candidates into classes of Favourite, Acceptable and Disapproved (Yilmaz, 1999). Then, the candidates are compared pair-wisely so that a candidate gets a vote each time when it is ranked higher than the pair. If one candidate has a majority of votes against all others, it is chosen. Otherwise, the candidate with most disapproval votes is eliminated. Then, the procedure is applied again until the winner can be found.

The Borda count (Saari, 1994) takes into account the whole preference ordering. With it, given $\mathrm{n}$ candidates, each voter gives $\mathrm{n}$ votes for the most preferred candidate, $n-1$ votes for the second most preferred one and finally 1 vote for the least preferred candidate. The winner is the candidate getting the most votes altogether.

Also voting methods based on pairwise comparisons exist. For example, the Condorcet winner is a choice obtaining the majority of votes against any other alternative in pairwise elections. However, it may happen that no Condorcet winner exists.

The voting systems mentioned above use only information concerning the preference ordering of the alternatives. Utilitarian voting systems consider also information on the intensity of preferences. They have a lot of common with MCDS methods. For example, in cumulative voting system, each voter is given a number of votes he or she can distribute to the candidates in any way: all votes can, for instance, be given to one candidate or many candidates can be given an equal number of votes (Kangas et al., 2006). This is similar to the prioritisation principles of SMART.

\section{AN EXAMPLE OF VOTING WITHIN SWOT: VotSWOT}

Finland is aiming at a low-carbon and resource-efficient society and a sustainable economy. This goal of central importance is related to the development of sustainable bio-economy, which relies on the use of renewable natural resources instead of nonrenewable ones. In Finland, sustainable use of forest resources is a key element in sustainable bio-economy, since forests and wood form the most abundant renewable natural resource in the country. The Finnish Bioeconomy Strategy aims at generating new economic growth and new jobs from an increase in the bio-economy business and from high-added-value products and services. At the same time, the nature's ecosystems must be maintained and secured.

At the University of Eastern Finland (UEF), the bio-economy research strategy is under preparation. Different aspects of bioeconomy are identified in various faculties and departments of UEF. Critical discussions are taking place so that the role of bioeconomy in the strategy of UEF can be defined. Should it be, in one end, the main driver of the overall strategy for the next 5 to 10 years, or, in another end, taken just as a transient buzzword that does not deserve any special strategic attention. One additional 
driver to the discussions comes from the fact that in Finland, especially in the forested regions such as eastern Finland, the role of forests in the promotion and success of bioeconomy is crucial.

Building a coherent and widely accepted bio-economy research strategy for UEF is not necessarily an easy task. For illustrative purposes, the situation is greatly simplified here. In the next step of the practical process, more deeper and versatile use of A'WOT and, e.g., more complicated voting might be applied. The example presented here is a simulation for illustrating how VotSWOT could be utilized in the strategy process. Nevertheless, also a simplified case formulation and corresponding decision support exercises might help in constructing the strategy process and its end-result and in inducting people with different pre-views and from different schools to a mutually understandable discourse.

Possible future scenarios for the operational environment are an important element of any strategy process. Formulation of the final strategy depends highly on the anticipated probabilities of the scenarios; in which kind of a scenario we believe? There are two basic alternatives as to how to approach the analysis of scenarios. It is possible to create for each possible scenario its own SWOT, and then perform A'WOT analyses. Another, a simpler and more straightforward way is to think that possible scenarios are implicitly covered when pondering factors in each SWOT category, especially the opportunities and threats as they clearly refer to the future. In the case example below, the latter way is adopted. That being the case, the thought probabilities of the possible scenarios reflect also to the comparisons of the importance of the SWOT factors.
In our VotSWOT exercise, we have three participants. First, the basic strategic choice alternatives are formed. The formulation of the final strategy, for example, directs the strategic and other research funding within the University, and gives a firm support when applying competitive funding from outside sources for those directions of research that have been chosen to be especially focused on. Let the basic alternatives be as follows:

(A) Bio-economy does not deserve any special attention neither in the society at large nor at the University; do not put any extra efforts on bio-economy training and R\&D\&I

(B) Bio-economy is important for the country's future, and it should be approached in versatile ways to form a many-sided and sound basis for its development; at the University, extra emphasis is put on bioeconomy research, but in order to form a many-sided basis for the societal development let all the "bio-economy flowers" flourish

(C) Bio-economy is important for the country's future, and the key factors for future bio-economy potential are related to the chemistry and physics of processing new products, and social and marketing aspects of the growing bio-economy; at the University, the main focus should be put correspondingly

(D) Bio-economy is of very central strategic importance for the whole society and forests are in its core in Finland; at the University strong emphasis should be given to forest and wood related bio-economy studies, and other research has a supportive role for them.

Second, the long-lists of SWOT-factors are produced. All the factors coming into minds of participants are listed, and then 
grouped together by the participants into groups of similar factors to get condensed lists of SWOT-factors. Similar factors may be merged.

Next step is approval voting among the condensed lists. Within each group, five most relevant factors are elected using approval voting scheme. For each group, every participant determines, which factors he/she thinks should be seriously considered when making the University's strategic choices. All the factors he/she chooses as being important get one vote each. The factors in each SWOT group are listed according to the sum of votes given by the participants. Five mostly approved factors in each group are chosen for further VotSWOT analysis (Table 1).

In the next phase, cumulative voting is applied so that the relative importance of the five factors within each SWOT group can be determined. All the participants get 100

\section{Table 1. The SWOT factors chosen in approval voting; a training example}

\begin{tabular}{|c|c|}
\hline SWOT group & SWOT factors \\
\hline Strengths & $\begin{array}{l}\text { S1 The University is really multidisciplinary } \\
\text { S2 Impact on the society's development is important for the University } \\
\text { S3 Good co-operation possibilities with Natural Resources Institute Finland, } \\
\text { Finnish Environment Institute, and the European Forest Institute } \\
\text { S4 Skills and scientific merits in rural area, forest and wood related bio- } \\
\text { economy } \\
\text { S5 Also scientists in chemistry, social sciences, jurisprudence, economics, } \\
\text { physics, biology are interested in bio-economy research }\end{array}$ \\
\hline Weaknesses & $\begin{array}{l}\text { W1 Bio-economy research at the University has no co-ordination over } \\
\text { departments } \\
\text { W2 There is no technical faculty at the University } \\
\text { W3 There is hesitation about the future importance of bio-economy studies } \\
\text { W4 Not enough co-operation with practical business world actors } \\
\text { W5 Versatile strengths of the University are not widely known }\end{array}$ \\
\hline Opportunities & $\begin{array}{l}\text { O1 Growing external research funding available for studies on bio-economy } \\
\text { O2 Future success of the national economy of Finland relies upon renewable } \\
\text { natural resources, especially forests and wood } \\
\text { O3 More intensive co-operation with technical universities and technical } \\
\text { faculties of other universities in wood material science and in studying new } \\
\text { bio-products } \\
\text { O4 Finnish forest industries' plans for investments on bio-refineries and on } \\
\text { wood-based products, also in eastern Finland } \\
\text { O5 Increasing multidisciplinary co-operation with bio-economy business } \\
\text { practice }\end{array}$ \\
\hline Threats & $\begin{array}{l}\text { T1 Price of oil remains low and the hyping for bio-economy ends shortly } \\
\text { T2 Growing interest on bio-economy makes research at the University too } \\
\text { one-sided } \\
\text { T3 Emphasising close connections with actors of practical business world } \\
\text { decrease the weight of basic research and of the freedom of research at the } \\
\text { University } \\
\text { T4 International and national political decisions do not favour bio-economy } \\
\text { any longer } \\
\text { T5 Funding for research infrastructure and equipment gets lower }\end{array}$ \\
\hline
\end{tabular}


votes to be allocated among the factors in each group. For example, within the Opportunities group Participant 1 may give 40 votes for $\mathrm{O} 2,25$ votes for $\mathrm{O} 4$ and $\mathrm{O} 5,10$ votes for $\mathrm{O} 3$, and 0 votes for $\mathrm{O} 1$ (Table 2.).

Cumulative voting is also used for mutual weighting of the SWOT groups. Each participant has 100 votes to be allocated for the SWOT groups according to their relevance in the University's bio-economy strategy. Weights for SWOT groups are calculated as the sums of votes, scaled to sum up to one. (Table 3).

As a result of the voting procedures, global priorities can be calculated for each SWOT factor, reflecting their relevance in the strategy process. If no consensus could be reached on the choice of the basic strategy among A-D, it would be possible to proceed the exercise by evaluating the strategy alternatives with respect to all the SWOT factors, e.g., by cumulative voting. In our example - as the Opportunities get the highest priority and forest and wood related issues are emphasized by them - it seems evident that the chosen basic strategy at this phase would be D. It must be emphasized that this would be just the basic choice, from where the strategy process continues by more detailed strategy formulation, most probably towards $\mathrm{C}$ or B to some extent.

Table 2. Cumulative voting for the SWOT factors by 3 participants; a training example

\begin{tabular}{llllll}
\hline SWOT group & Factors & Participant 1 & Participant 2 & Participant 3 & Sum of votes \\
\hline Strengths & S1 & 10 & 5 & 20 & 35 \\
& S2 & 10 & 0 & 20 & 30 \\
& S3 & 30 & 10 & 20 & 60 \\
& S4 & 20 & 10 & 20 & 50 \\
& S5 & 30 & 75 & 20 & 125 \\
Weaknesses & W1 & 15 & 10 & 25 & 50 \\
& W2 & 15 & 0 & 10 & 25 \\
& W3 & 50 & 50 & 20 & 120 \\
& W4 & 10 & 20 & 30 & 60 \\
Opportunities & W5 & 10 & 20 & 15 & 45 \\
& O1 & 0 & 15 & 20 & 35 \\
& O2 & 40 & 20 & 5 & 65 \\
& O3 & 10 & 25 & 40 & 75 \\
Threats & O4 & 25 & 20 & 30 & 45 \\
& O5 & 25 & 10 & 5 & 25 \\
& T1 & 5 & 20 & 0 & 20 \\
& T2 & 10 & 0 & 10 & 15 \\
& T3 & 5 & 0 & 10 & 140 \\
& T4 & 40 & 50 & 50 & 100 \\
\hline
\end{tabular}

Table 3. Cumulative voting for the SWOT groups by 3 participants; a training example

\begin{tabular}{lccccc}
\hline SWOT group & Participant 1 & Participant 2 & Participant 3 & Sum of votes & Scaled \\
\hline Strengths & 20 & 30 & 30 & 80 & 0.267 \\
Weaknesses & 15 & 15 & 10 & 40 & 0.133 \\
Opportunities & 40 & 35 & 40 & 115 & 0.383 \\
Threats & 25 & 20 & 20 & 65 & 0.217 \\
\hline
\end{tabular}




\section{DISCUSSION}

Active application of MCDS methods to support SWOT clearly indicates that they have the potential of deepening the SWOT analyses. The A'WOT approach with various versions has gained considerable use and popularity in many different areas worldwide (Shrestha et al., 2004; Masozera et al., 2006; Shinno et al., 2006; Cenzig et al., 2007; Kajanus et al., 2012; Okello et al., 2014; Bottero, 2015; Nikolić et al., 2015; Posch et al., 2015).

Most often, the MCDS technique used has been the AHP. The SMART-SWOT hybrid approach, in turn, has been used in cases such as evaluating the role of universities in regional innovation systems (Năstase \& Kajanus, 2008), examination of the role of innovations in forestry- and agriculturerelated case study enterprise (Kajanus, 2009), and in examining the development possibilities of regional forest program processes in Finland in different development scenarios of the society (Kurttila et al., 2009).

The Analytic Network Process (ANP) (Saaty, 1996) has been used instead of AHP when dependencies between strategic factors were under consideration (Yüksel \& Dagdeviren, 2007). Recently, ANP-SWOT approach was applied in analyzing the development of tourism industry in Iran (Heidari et al., 2014). The ANP-SWOT was found as a viable and highly capable methodology, providing invaluable insights for complex strategic management decisions.

Results from Uganda showed that the use of the AHP method in SWOT (i.e. basic $A^{\prime}$ WOT) is effective in evaluating stakeholder preferences for bioenergy technologies, and the hybrid method could be used as a tool for technology screening, or reaching consensus in a participatory setup in a transparent manner (Okello et al., 2014). Another study found that the combination of SWOT and the AHP is a valuable tool for strategic energy management (Posch et al., 2015). A'WOT has also been applied to assessing the sustainability of urban forests (Bottero, 2015). This study pointed out that the A'WOT approach is successful in structuring a complex planning context and in increasing and improving the information. According to that study, the hybrid framework is able to communicate the planners', designers' and decision maker's perspectives, to enhance transparency in the decision process and thus to increase acceptance, as well as to act as a learning process. Our experiences gained through A'WOT applications are in line with those of the above-mentioned studies (Kajanus et al., 2012).

Increasing complexity into an analysis always means need for more assessments to be made. Time needed is always a critical constraint, and there is a need to develop faster and easier to use but still trustable enough methodologies. Voting methods are interesting in this respect. The very basic ideas behind voting methods and MCDS methods are quite similar. Some of them are close to each other technically, too. For example, some modification of SMART and cumulative voting can, practically taken, be regarded as one and the same method, although they have different theoretical backgrounds.

Combined use of SWOT, SMART and voting methods has also been reported (Pezdevšek Malovrh et al., 2015). The main methodological difference of this application compared to the example case in this article was that it formulated separate sub-classes under each SWOT field and then performed 
MCDS analyses separately for each scenario. However, the processing of the SWOT factors separately for each different scenario could be useful in some cases, although it makes the analysis more complicated and more difficult to follow. This allows us examine, for instance, which of the strategic factors are important in all scenarios and which of them should be taken into account in only some specific scenarios. If the formulation of strategy alternatives is needed, the strategic factors and their priorities in different scenarios provide a basis for directing future operations in an adaptive manner. Applying that kind of a scenario approach, however, makes it harder to understand and more time-consuming. That is why it is at its best when only experts are involved in the strategy process.

The A'WOT method with SMART has been found easy both for experts and for participants in the regional work programme to understand and apply (Kurttila et al., 2009). This surely is the case with cumulative voting - SWOT hybrid method, as well. However, although calculations of SMART and cumulative voting are probably easier to carry out than calculations of the AHP, the provision of ratings to all factors within the specific SWOT field simultaneously can be more difficult.

When SMAA-O is applied in a SWOT framework, it is not necessary to determine any importance neither of the factors nor the groups in the first phase. Central weight vectors can be applied to study which importance best support the choice of each decision alternative. Together with rank acceptability indices, they serve as a good starting-point for an interactive process, finally resulting in the choice of one alternative. During the process, information on the importance orders of SWOT factors and SWOT groups is included step by step. Before the importance order of SWOT groups is determined, it might be useful to examine the priorities of the decision alternatives within each group. This provides training and learning about the selection problem.

\section{CONCLUSION}

It can be concluded that hybrid methods of MCDS or voting and SWOT can be applied to increase and improve the information basis of strategic planning processes. They may provide not only a solid decision support but also an effective framework for learning in strategic decision support in numerous situations. They can also be used as tools in communication and education in decision-making processes where multiple decision-makers or judges are involved (Bottero, 2015). In participatory processes, the less the participants have expertise on methodology and on the subject in question the more recommendable it is to apply simple voting methods instead of more complicated MCDS.

Nevertheless, the utilization of the specific MCDS or voting method is always a case-specific question. Generally taken, simple preference information enables easy questions that decision-makers and other participants need to answer, but at the same time the possibilities of giving versatile decision support are limited. According to our experiences, the choice of the appropriate MCDS or voting method in SWOT should be based on consideration of all the stakeholders' abilities to provide different levels of preference information and the required decision support. 


\section{Acknowledgement}

This research has been supported by the Strategic Research Project on Sustainable, climate-neutral and resource-efficient forestbased bioeconomy (FORBIO, proj. 14970), led by Prof. Heli Peltola, at the School of Forest Sciences, University of Eastern Finland (UEF) and funded by the Academy of Finland under the Climate-Neutral and Resource-Scarce Finland - Strategic Research Programme in 2015-2020.

\title{
ИНТЕГРАЦИЈА ТЕХНИКА МЦДС И РАНГИРАҢА У СВОТ АНАЛИЗУ - ОСНОВНЕ ИДЕЈЕ И ПРАКТИЧНА ИСКУСТВА
}

\author{
Jyrki Kangas, Miika Kajanus, Pekka Leskinen, Mikko Kurttila
}

\section{Извод}

Идеја у коришћењу вишеструких критеријума за подршку одлучивању (МЦДС) и метода гласања у СВОТ оквиру, садржи се у покушају систематске процене СВОТ фактора, са аспеката њиховиџ приоритета. Метод МЦДС који се најраније и најчешће примењивао био је Аналитички хијерархијски процес (АХП), док је хибридни АХП-СВОТ приступ анализи назван А'ВОТ. Било који МЦДС поступак може, међутим, бити примењен у циљу анализе представљене у овом раду; јер је избор метода у зависности од стратегијског процеса који се истражује. У овом чланку, сумирана су искуства примене метода А'ВОТ са АХП, СМАРТ и СМАА-О техникама. Поред тога, као илустративни пример дато је коришћење теорије друштвеног избора у СВОТ оквиру . Хибридни МЦДС-СВОТ анализа приступ стиче све већу популарност и примењује се у различитим областима истраживања. Он може да обезбеди не само солидну подршку одлучивању,, већ и ефикасан оквир за учење о подршци стратегијског одлучивања, као и за комуникацију у цтратегијским процесима са више заинтересованих страна. Приступ Рангирање-СВОТ (ВотСВОТ) посебно је добро примењив код одговара посебно добро код партиципативних стратегијских процеса, будући да одражава природне начине комиуникације између доносиоци одлука и заинтересованих страна.

Кључне речи: А'ВОТ, подршка вишекритеријумском одлучивању, управљање природним ресурсима, цтратегијски менаџмент, методе рангирања

\section{References}

Alho, J.M., \& Kangas, J. (1997). Analyzing uncertainties in experts' opinions of forest plan performance. Forest Science, $43,521-528$.

Barzilai, J., \& Lootsma, F.A. (1997). Power relations and group aggregation in the multiplicative AHP and SMART. Journal of Multi-Criteria Decision Analysis, 6, 155165.
Bottero M. (2015). A multimethodological approach for assessing sustainability of urban projects. Management of Environmental Quality, 26, 138-154.

Cengiz, K., Çetin, K.N., \& Tufan, D. (2007). Prioritization of e-Government strategies using a SWOT-AHP analysis: the case of Turkey. European Journal of Information Systems, 16, 284-298.

De Jong, P. (1984). A statistical approach to Saaty's scaling method for priorities. 
Journal of Mathematical Psychology, 28, 467-478.

Edwards, W., \& Barron, F.H. (1994). SMARTS and SMARTER: Improved simple methods for multiattribute utility measurements. Organizational Behavior and Human Decision Processes, 60, 306-325.

Heidari, M., Ashari, H.A., Farahbakht, S., \& Parvaresh, S. (2014). Using the Analytic Network Process (ANP) in a SWOT analysis for the development of tourism destination case study: Kish Island. International Journal of Management, 5 (6), 21-21.

Helms, M.M., \& Nixon, J. (2010). Exploring SWOT analysis - where are we now? A review of academic research from the last decade. Journal of Strategy and Management, 3 (3), 215-251.

Kajanus, M. (2009). INNO-FOREST Integrating Innovation and Entrepreneurship Research in Higher Forestry Education lessons learnt from Erasmus Intensive Programme. Savonia University of Applied Sciences. Research and development. Series D 1/2009, 1-57.

Kajanus, M., Leskinen, P., Kurttila, M., \& Kangas, J. (2012). Making use of MCDS methods in SWOT analysis - Lessons learnt in strategic natural resources management. Forest Policy and Economics, 20, 1-9.

Kangas, J., Kurttila, M., Kajanus, M., \& Kangas, A. (2003). Evaluating the Management Strategies of a Forestland Estate - the S-O-S approach. Journal of Environmental Management, 69, 349-358.

Kangas, A., Laukkanen, S., \& Kangas, J. (2006). Social choice theory and its applications in sustainable forest management - a review. Forest Policy and Economics, 9, 77-92.

Kurttila, M., Pesonen, M., Kangas, J., \& Kajanus, M. (2000). Utilizing the analytical hierarchy process (AHP) in SWOT analysis -
A hybrid method and its application to a forest-certification case. Forest Policy and Economics, 1, 41-52.

Kurttila, M., Leskinen, P., Tikkanen, J., \& Niskanen, A. (2009). Developing regional forest programmes from the viewpoint of operational environment. Metsốtieteen aikakauskirja, 3/2009, 183-197. (in Finnish)

Lahdelma R., Hokkanen, J., \& Salminen, P. (1998). SMAA - Stochasätic multiobjective acceptability analysis. European Journal of Operational Research, 106, 137-143.

Leskinen, P., Kangas, A.S., \& Kangas, J. (2004). Rank-based modelling of preferences in multi-criteria decision making. European Journal of Operational Research, 158, 721-733.

Leskinen, P., \& Kangas, J. (2005). Multicriteria natural resource management with preferentially dependent decision criteria. Journal of Environmental Management, 77, 244-251.

Martin, W.E., Schields, D.J., Tolwinski, B., \& Kent, B. (1996). An application of social choice theory to U.S.D.A. Forest Service decision making. Journal of Policy Modelling, 18, 603-621.

Masozera, M.K., Alavalapati, J.R.R., Jacobson, S.K., \& Shrestha, R.K. (2006). Assessing the suitability of communitybased management for the Nyungwe Forest Reserve, Rwanda. Forest Policy and Economics, 8, 206-216.

Miettinen, K., Lahdelma, R., \& Salminen, P. (1999). SMAA-O - Stochastic Multicriteria Acceptability Analysis with Ordinal criteria. Reports of the Department of Mathematical Information Technology, Series B, Scientific computing No. B 5/1999. University of Jyväskylä.

Năstase, C., \& Kajanus, M. (2008). The role of the universities in a regional 
innovation system - a comparative A'WOT Kalmbacher, R.S. (2004). Exploring the analysis. Economic Interfaces, 23, 219-224.

Nikolić, Dj., Spasić, J., Živković, Ž., Djordjević, P., Mihajlović, I., \& Kangas, J. (2015). SWOT - AHP model for prioritization of strategies of the resort Stara Planina. Serbian Journal of Management, 10 (2), 141-150.

Nurmi, H. (1995). On the difficulty of making social choices. Theory and Decision, 38, 99-119.

Okello, C., Pindozzi, S., Faugni, S., \& Boccia, L. (2014). Appraising Bioenergy Alternatives in Uganda Using Strengths, Weaknesses, Opportunities and Threats (SWOT) - Analytical Hierarchy Process (AHP) and a Desirability Functions Approach. Energies, 7, 1171-1192.

Pezdevšek Malovrh, S., Kurttila, M., Hujala, T., Kärkkäinen, L., Leban, V., Lindstad, B.H., Peters, D.M., Rhodius, R., Solberg, B., Wirth, K., Zadnik Stirn, L., \& Krč, J. Evaluating the operational environment of forest bioenergy production and use in four European countries. Manuscript, in review process, 2015.

Posch, A., Brudermann, T., Braschel, N., \& Gabriel, M. (2015). Strategic energy management in energy-intensive enterprises: a quantitative analysis of relevant factors in the Austrian paper and pulp industry. Journal of Cleaner Production, 90, 291-299.

Saari, D.G. (1994). Geometry of voting, volume 3 of Studies in Economic Theory. New York: Springer-Verlag.

Saaty, T.L. (1980). The Analytic Hierarchy Process. New York: McGrawHill.

Saaty, T.L. (1996). Decision Making with Dependence and Feedback: The Analytic Network Process. Pittsburgh: RWS Publications.

Shrestha, R.K., Alavalapati, J.R.R., \& potential for silvopasture adoption in southcentral Florida: an application of SWOTAHP method. Agricultural Systems, 81 (3), 185-199.

Shinno, H., Yoshioka, H., Marpaung, S., \& Hachiga, S. (2006). Quantitative SWOT analysis on global competitiveness of machine tool industry. Journal of Engineering Design, 17 (3), 251-258.

Yilmaz, M.R. (1999). Can we improve upon approval voting? European Journal of Political Economy, 15, 89-100.

Yüksel, İ., \& Dagdeviren, M. (2007). Using the analytic network process (ANP) in a SWOT analysis - A case study for a textile firm. Information Sciences: an International Journal, 177, 3364-3382. 